San Jose State University

SJSU ScholarWorks

Master's Theses

Master's Theses and Graduate Research

Spring 2019

\title{
The Effect of Precipitation on Copy Number of Nitrogenase Gene nifH in Soil Bacteria in the Mojave Desert
}

Christy Armstrong

San Jose State University

Follow this and additional works at: https://scholarworks.sjsu.edu/etd_theses

\section{Recommended Citation}

Armstrong, Christy, "The Effect of Precipitation on Copy Number of Nitrogenase Gene nifH in Soil Bacteria in the Mojave Desert" (2019). Master's Theses. 4993.

DOI: https://doi.org/10.31979/etd.mpfm-2w3d

https://scholarworks.sjsu.edu/etd_theses/4993

This Thesis is brought to you for free and open access by the Master's Theses and Graduate Research at SJSU ScholarWorks. It has been accepted for inclusion in Master's Theses by an authorized administrator of SJSU ScholarWorks. For more information, please contact scholarworks@sjsu.edu. 
THE EFFECT OF PRECIPITATION ON COPY NUMBER OF NITROGENASE GENE nifH IN SOIL BACTERIA IN THE MOJAVE DESERT

\author{
A Thesis \\ Presented to \\ The Faculty of the Department of Biological Sciences \\ San José State University \\ In Partial Fulfillment \\ of the Requirements for the Degree \\ Master of Science
}

by

Christy Armstrong

May 2019 
(C) 2019

Christy Armstrong

ALL RIGHTS RESERVED 
The Designated Thesis Committee Approves the Thesis Titled

THE EFFECT OF PRECIPITATION ON COPY NUMBER OF NITROGENASE GENE nifH IN SOIL BACTERIA IN THE MOJAVE DESERT

by

Christy Armstrong

APPROVED FOR THE DEPARTMENT OF BIOLOGICAL SCIENCES

San José State University

May 2019

Sabine Rech, Ph.D.

Department of Biological Sciences

Cleber Ouverney, Ph.D.

Department of Biological Sciences

Luke Miller, Ph.D.

Department of Biological Sciences, San Diego State University 


\title{
ABSTRACT
}

\section{THE EFFECT OF PRECIPITATION ON COPY NUMBER OF NITROGENASE GENE nifH IN SOIL BACTERIA IN THE MOJAVE DESERT}

\author{
by Christy Armstrong
}

Animals, plants, and microbes all rely on nitrogen to be readily available to build amino acids. The earth's atmosphere is made of $78 \%$ nitrogen gas, but this molecule has a strong triple bond that prevents many species from utilizing it directly. Nitrogen fixation must occur in order for individuals to incorporate this nitrogen into their genome. The Mojave Desert is the most arid region in North America, averaging 3.5 inches of rain annually at its lowest elevation. Despite the extreme arid conditions, many species are supported in the region, all of which must rely on some form of nitrogen. This research addresses how aridity affects nitrogen fixation rates in soil microorganisms. It is predicted that there will be an increase in the nitrogen-fixing gene number, nifH, in more arid climates. Soil samples were collected from four sites across a 153-mile precipitation transect of the Mojave Desert, ranging from semi-arid to arid climates, over three years. Genomic DNA was isolated and quantified. Quantitative PCR was performed with primers targeted at the nifH gene of nitrogenase. Nitrogenase gene copy number tended to increase in more arid regions. Site number and yearly precipitation had significant effects on total nifH abundance. Percent crust and percent vegetation had significant effects on the 2009 sites. These results show that there is the potential for higher levels of nitrogen fixation in arid regions, which can be affected by yearly precipitation or other site factors. 


\section{ACKNOWLEDGMENTS}

Dr. Rech - Thank you for being an outstanding mentor throughout my journey at San Jose State. You were always a great sounding board for my ideas. You also made sure I did not get too off track with my experiment. Thank you for always listening and inspiring me to be my best.

Dr. Ouverney - Thank you for your technical help throughout this process. You were always helpful in explaining what techniques were needed and what the best way to perform them were.

Dr. Miller - Thank you for your help with statistics and for staying on my committee even though you had a big transition to San Diego in the works.

Friends and Family - Thank you for all your love and support. 


\section{TABLE OF CONTENTS}

List of Tables................................................................. vi

List of Figures................................................................ vii

Chapter 1. Literature Review........................................... 1

Introduction ......................................................... 1

Biogeochemical Cycles ............................................... 1

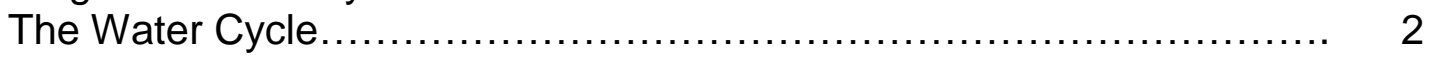

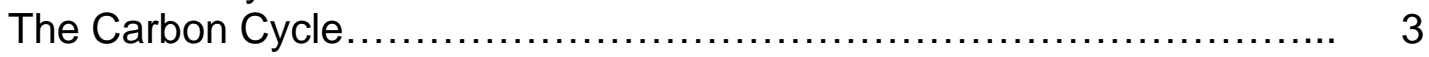

The Nitrogen Cycle................................................... 4

Interactions Between Cycles.......................................... 6

Nitrogenase Enzyme................................................... 7

Nitrogenase and Plants............................................... 8

Nitrogen Cycling in Arid Environments ................................ 10

Impact of Research................................................... 12

References............................................................ 14

Chapter 2. Manuscript................................................... 18

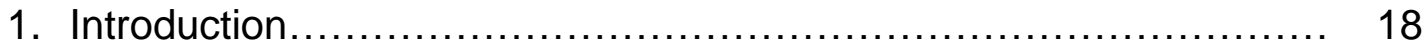

2. Site Description................................................. 20

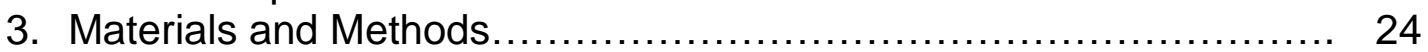

3.1. DNA Extraction.......................................... 24

3.2. nifH Amplification in Anabaena............................... 25

3.3. Cloning and Sequencing.................................... 26

3.4. Quantitative PCR (qPCR) Standard Curve .................... 26

3.5. gPCR Soil Samples from years $2008-2010 \ldots \ldots \ldots \ldots \ldots \ldots \ldots . . \ldots 28$

3.6. Statistical Analysis........................................ 28

4. Results........................................................... 29

4.1. Cloning and Sequencing .................................... 29

4.2. Quantitative PCR (qPCR) Standard Curve .................... $\quad 30$

4.3. $\quad$ gPCR of Soil Samples from years $2008-2010 \ldots \ldots \ldots \ldots \ldots \ldots . . . \ldots$

4.4. Statistical Analysis.......................................... 32

5. Discussion.......................................................... 37

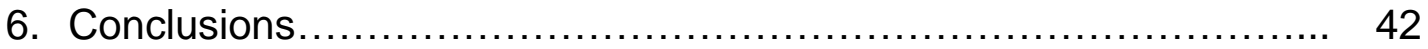

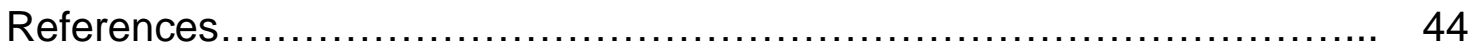




\section{LIST OF TABLES}

Table 1. Sample Sites in the Mojave Desert................................ 21

Table 2. Soil composition and abiotic factors associated with

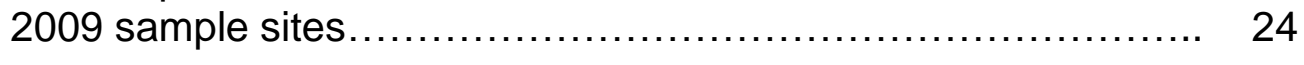

Table 3. nifH PCR primers.............................................. 25

Table 4. Colony Forming Unit (CFU) count for each site and

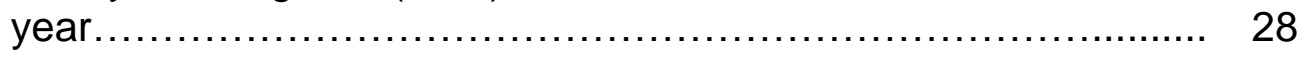

Table 5. Total gene copy number vs site factors over 3 years.............. 33

Table 6. Adjusted gene copy number vs site factors for 3 years............. 33 


\section{LIST OF FIGURES}

Figure 1. Precipitation amounts at DRI sites per year..................... 22

Figure 2. Precipitation amounts by year and site .......................... 23

Figure 3. Equation to determine gene copy number..................... 27

Figure 4. Comparison of cloned sequence to $\mathrm{nifH}$ sequence

in Anabaena cylindrica strain UTEX B629

(Sequence ID: AY768423.1)................................ 29

Figure 5. Standard curve generated from qPCR of cloned nifH gene in plasmid........................................... 30

Figure 6 . Total gene copy number of sample sites....................... 31

Figure 7. Adjusted gene copy number of sample sites.................... 32

Figure 8. ANOVA of 2009 soil and site composition factors on adjusted gene copy number................................. 34

Figure 9. ANOVA of 2009 soil and site composition factors on adjusted gene copy number................................. 36

Figure 10. PCA of 2009 factors........................................ 37 


\section{Chapter 1: Literature Review}

\section{Introduction}

Beginning in the late $19^{\text {th }}$ century, the average surface temperature of the earth has increased by a total of one degree Celsius (NASA, n.d.). Although this amount may seem negligible, it has already caused drastic changes of the earth and its ecosystems. The sea level has risen $250 \mathrm{~mm}$ since 1870 due to melting ice sheets near the poles (NASA, n.d.). Many organisms have experienced changes to the timing of their life cycles, including reproduction and migration. Species have shifted their habitat ranges to find livable conditions. Parasites have expanded their range since livable conditions are widening for them, and food webs are disrupted by these shifting ranges and diseases (EPA, 2017). Many aspects of the natural world are susceptible to this changing climate, including microbiota. The purpose of this study is to examine how alterations in climate can affect biogeochemical cycles, specifically the nitrogen cycle.

\section{Biogeochemical Cycles}

Biogeochemical cycling is important for the maintenance of all ecosystems. Without the constant depletion and renewal of essential nutrients, organisms would not be able to grow and thrive. The most important biogeochemical cycles circulate water, carbon, and nitrogen through different environments and ecosystems on earth. Anthropogenic effects, such as increased carbon emissions and agricultural runoff, are disrupting these cycles and can affect the survival and functioning of all living organisms. 


\section{The Water Cycle}

The water cycle is perhaps the most well-known biogeochemical cycle. Water evaporates from bodies of water on earth, and then condenses in the atmosphere to form rain, hail, or snow. The water returns to the earth's surface via precipitation, and the cycle continues. There have been interruptions in multiple aspects of this cycle caused by human activities, such as groundwater mining, urbanization, oxidation of fossil fuels, deforestation, destruction of wetlands, production of reservoirs, and installation of irrigation systems (Gornitz et al., 1997). These activities can have two main types of effects. Either they can cause an increase in the amount of water returning to large bodies of water, or conversely, they can decrease the movement of water. Urbanization causes an influx in water, because it decreases the amount of soil available to absorb the water. Soil surface area is replaced with cement which does not absorb water. Groundwater mining takes water out of the soil, leaving it to mobilize towards bodies of water instead (Gornitz et al., 1997). The combustion process releases water into the atmosphere which can then become precipitation. Destruction of wetlands and deforestation destroy ecosystems that utilize a large amount water, whether for trees or for waterlogged soils, which mobilizes the water towards bodies of water. Irrigation and reservoirs limit water movement in order to be used by humans for agriculture or personal use (Gornitz et al., 1997).

Changing water mobility causes a disruption to the water cycle and either a rise or fall in sea level. Man-made reservoirs, water consumption and withdrawal 
have minimal effects, but anthropogenic activities mainly involving irrigation runoff have a larger effect. Irrigation runoff is caused when there is a greater amount of water on the surface of the soil than can be absorbed. Contaminants and chemicals, such as pesticides and fertilizers, move with the excess water into lakes and oceans (Gardner, n.d.). Between the years 1950-2000, the United States saw an increased runoff rate of $1.04 \mathrm{~mm} /$ year. Climate change has the potential to make this effect larger; with increasing surface temperature, irrigation will be more necessary. Runoff is predicted to increase $7.3 \%$ by the year 2050 worldwide (Huntington, 2006; Haddeland et al., 2013).

\section{The Carbon Cycle}

Changes in climate have disrupted the carbon cycle as well. The natural carbon cycle starts with atmospheric carbon dioxide being sequestered by plants for photosynthesis. As the plants use this energy to grow, they can either transfer the carbon to primary consumers or return the carbon to the soil via decomposition. Decomposition of animals and their waste via fungi and bacteria can also return the carbon to the soil to be mobilized and utilized by other organisms (Riebeek, 2011). Respiration occurs in animals and plants, which releases carbon into the atmosphere in the form of carbon dioxide. However, increased industrialization and the burning of fuels derived from fossilized carbon

have increased the amount of carbon released in the atmosphere. Approximately $80 \%$ of carbon emissions are derived from the burning of fossil fuels (EPA, n.d.), which has significantly increased during the last century. 
Anthropogenic atmospheric carbon dioxide started to accumulate before industrialization, as early as the medieval era. However, the upsurge of the human population that accompanied the industrial era dramatically shifted the amount of carbon emissions by about 45-100 gigatons of carbon per square meter (Pongratz et al., 2009). With the increase in atmospheric carbon dioxide came an upsurge in the mean surface temperature of the earth, currently at a rate of 1.5 degrees Celsius per century (Lindsey and Dahlman, 2018). High atmospheric carbon levels can also cause the occurrence of acid rain, which has a lower $\mathrm{pH}$ than regular rain. Acid rain can disrupt other biogeochemical cycles by replacing natural weak acids with strong acids, which dissociates aluminum ions that are carried in runoff to bodies of water. These aluminum ions are toxic to fish and wildlife (Likens et al., 1981).

\section{The Nitrogen Cycle}

The nitrogen cycle is carried out mostly by microorganisms (MartinezEspinosa et al., 2011). Atmospheric nitrogen gas has a strong triple covalent bond that can only be broken by organisms with the nitrogenase enzyme which is produced by few genera of bacteria and archaea, known as diazotrophs. These microorganisms fix the nitrogen gas and produce ammonia. Another group of bacteria, known as nitrifying bacteria, use the enzymes ammonia oxidase and hydroxylamine oxidase to transfer the nitrogen from ammonia to oxygen to form nitrites. The enzyme nitric oxide synthase adds oxygen to form nitrates (Bernhard, 2010). Denitrifying bacteria revert nitrates into nitrogen gas to be 
returned to the atmosphere. The second aspect of the nitrogen cycle involves plants. Plants obtain nitrogen in the form of ammonia that is produced by diazotrophs, such as the symbiotic genus Rhizobium or the free-living genus Azotobacter. Higher organisms consume the plants as a nitrogen source. When decomposition occurs, fungi and bacteria break down organisms to return nitrogen to the soil in the form of ammonia (Bernhard, 2010). Some fungi, such as polypores (commonly known as shelf fungi that grow on trees), can decompose organisms independently, however, other fungi live in symbiosis with cyanobacteria in lichen. In lichen, cyanobacteria provide energy to the fungi, while the fungi supply the cyanobacteria with protection ("Ecology of Fungi", n.d.).

The nitrogen cycle can also be affected by the effects of humans. The main sources of anthropogenic effects are industrial emissions, agricultural emissions, and livestock emissions (Lagzi et al., 2013). Nitrous oxide, like carbon dioxide, is a byproduct of fossil fuels that is released into the atmosphere. Nitrous oxide gas makes up $6 \%$ of greenhouse gases, which contribute to trapping heat in the atmosphere (EPA, n.d.). However, the greatest effect humans have had on the nitrogen cycle involves the agriculture industry. The use of artificial fertilizers to supplement nutrient-limited soil has had a negative effect on the environment; it produces an unnatural influx of nitrogen that cannot be supported by the environment (Bernhard, 2010). Diazotrophs cannot thrive since they are not needed for the production of ammonia, and excess inorganic fertilizer causes 
runoff during rainy seasons that eventually makes its way to the ocean (Norman and Friesen, 2017). Once in the ocean, excess nutrients can cause algal blooms that can affect the food chain of higher organisms. Algal blooms are also exasperated by increased surface temperature (Bernhard, 2010). Algal blooms can be formed by cyanobacteria or a combination of diatoms and dinoflagellates. They are detrimental, because they can produce toxins, sequester the oxygen in the ocean necessary to maintain the ecosystem, clog up fish gills, and smother reefs ("What is Harmful", 2016). Also, the use of artificial fertilizers can pair with unnaturally high atmospheric carbon to produce acid rain and mobilize aluminum ions that are toxic to wildlife (Likens et al., 1981).

\section{Interactions Between Cycles}

Biogeochemical cycles do not solely interact with the climate; they also interact with each other. The hydrological cycle participates in the movement of all nutrients through the environment. In temperate and tropical areas, humidity promotes decomposition, leaching, erosion and mineralization of carbon, nitrogen, sulfur and phosphorus (Likens et al., 1981). However, when available water is limited, these processes are unstable. Less plant primary production occurs, which leads to less decomposition and mobilization of nutrients. Increased global temperatures will decrease precipitation in most areas. This could lead to decreases in nutrient mobilization through various ecosystems.

Nutrient instability is not only associated with availability of water. Gosz et al.(1973) found that the ratio between carbon and nitrogen and the ratio between 
carbon and phosphorus were essential for mineralization of nutrients during the process of decomposition. They did this by measuring element amounts in decomposing leaf litter. $\mathrm{C}: \mathrm{N}$ ratios were between $20: 1$ and 30:1 in their sample sites, and C:P ratios were 480:1. When ratios are higher than these amounts, immobilization of the nutrients occurs. Immobilization prevents nutrients from being accessible to plants. When ratios are lower than these amounts, decomposition continues in order to mineralize the nutrients (Gosz et al., 1973). Mineralization is critical for mobilizing nutrients to plants and primary consumers. The nitrogen cycle is also known to interact with the sulfur cycle. There is a negative correlation between nitrate concentration and sulfate concentration in bodies of water near deforestation sites and in drainage sites (Likens et al., 1970). This phenomenon is not well understood. The inverse relationship could be due to high sulfate concentrations being toxic to bacteria that cycle nitrogen (Liu et al., 2014). However, it has been proposed that nitrates have an effect on sulfates as well. With the accumulation of nitrates in precipitation in the United States and Europe, there could be a severe decrease in available sulfates, which could negatively impact the sulfur cycle (Likens et al., 1977; Soderlund, 1977; Likens, 1976). The nitrogen cycle interacts with the other nutrient cycles; thus, it is important to study it thoroughly, starting with the beginning, nitrogen fixation.

\section{Nitrogenase Enzyme}

The nitrogenase enzyme is found in certain species of archaea and bacteria in terrestrial and aquatic habitats. Nitrogenase reduces atmospheric nitrogen $\left(\mathrm{N}_{2}\right)$ 
to ammonia $\left(\mathrm{NH}_{3}\right)$ and consists of two proteins. The first protein, dinitrogenase reductase, is an iron protein that transfers electrons to the dinitrogenase protein. The second iron protein, dinitrogenase, binds to $\mathrm{N}_{2}$. In dinitrogenase, the iron can be bound to molybdenum (most common), vanadium, or neither (Berges and Mulholland, 2008). These two proteins are encoded by the gene complex nifHDK. Dinitrogenase is specifically encoded by nifD and nifK, while dinitrogenase reductase is encoded by nifH (Skot, 2003). There are instances of variation in these structural genes and their sequences, however nifH is required for encoding of the nitrogenase enzyme (Zehr et al., 2003).

\section{Nitrogenase and Plants}

Nitrogenase is necessary for almost all ecosystems to function, so nifH has been studied in detail. However, most of the research has involved plants either in relation to agriculture or restoration of lands disturbed by human activity. Orr et al. (2011) studied the effect of different soil management techniques on diversity and activity in diazotrophs. They found that an important indicator of nitrogen fixation activity and diazotroph diversity was the type of crop that was planted the previous month. Plots that previously contained barley consistently had more nitrogenase activity and diversity through all planting seasons.

Not surprisingly, other studies have identified plants as being important to nitrogen fixation. This was studied in arid environments by Koberl et al. (2016) by using quantitative Polymerase Chain Reaction (qPCR) to estimate gene copy number. Molecular fingerprinting and pyrosequencing were used to analyze 
diversity. They found that the desert agricultural study site had higher diazotroph diversity and 1.5 -fold more nifH gene copies than native desert sites. They also suggested that aridity might have increased diversity and abundance of nitrogenase genes compared to other climates. This could be because of the limitation of available nitrogen. In areas with reduced available nitrogen, the nitrogenase gene is more prevalent since there is less competition with nondiazotrophs. The nitrogenase enzyme allows these bacteria to survive nitrogen limitation (Zehr et al., 2003). Diazotrophs can restore nitrogen to the ecosystem as long as enough phosphorus is available to sustain energy levels (Vitousek, 1999). No studies have been done to show that these suggestions are consistent with nature.

Plants have also proved to be a useful resource in the restoration of arid environments. Lopez-Lozano et al. (2016) analyzed three desert sites, one that was undisturbed, one that was disturbed, and one that was previously disturbed, but was restored using native plants. The disturbed sites had been cleared of vegetation to build a road in the 1980s. Half of the site was restored in 2004 . The restored site had a higher potential for nitrogen fixation and was not significantly different in diazotroph abundance than the undisturbed site. The type of plants used were also essential to the propagation of diazotrophs. Leguminous trees had a higher abundance of diazotrophs than other plant species and a higher potential for nitrogen fixation (as determined by an acetylene reduction assay). All sites with plants had a higher diversity of diazotrophs than sites not 
associated with plants (Lopez-Lozano et al., 2016). Plant species and sampling sites had the largest impact in nitrogen fixation capabilities. Diazotroph abundance, potential nitrogen fixation and diazotroph diversity were all significantly affected by plant species and sampling sites. However, the amount of organic matter and the amount of sand also had a significant effect on diazotroph abundance. (Lopez-Lozano et al., 2016).

Decomposition of organic matter will lead to an increase of soil nitrogen. Sand or soil type in general has been shown to affect nifH gene patterns, as well as respiration, denitrification, mineralization of organic matter and bacterial population structure by changing the amounts of nutrients and water available to microorganisms (Poly et al., 2001). This is due to the fractionation of the soil. Fractionation is determined by the size and density of soil particles. Soils with higher fractionation have larger gaps in between soil particles, which can allow microorganisms to have more access to nutrients but can also cause higher rates of desiccation in those microorganisms (Poly et al., 2001).

\section{Nitrogen Cycling in Arid Environments}

Desiccation does not permanently prevent nitrogenase activity. In Antarctica, it was found that nitrogenase activity was restored in a desiccated site when water was replenished by melting of ice (Olson et al., 1998). Olson et al. collected ice aggregates and soil samples from Lake Bonney, Antarctica. They used the acetylene reduction assays to determine nitrogenase activity and PCR amplification and cloning to analyze diversity. They found desiccation did not 
prevent bacterial diversity in the arid and nutrient-poor Antarctica. The nifH gene was isolated from both bacteria and cyanobacteria and fifteen diverse sequences were found within soil and ice aggregates. They also found that there was nitrogenase activity in the samples, although it was 10,000 -fold less than a temperate control (Olson et al., 1998).

Not much research has been done on the effects of aridity on nitrogenase gene abundance in soil bacteria, but there has been research on the effects of aridity on ammonia-oxidizing soil bacteria and archaea. Ammonia oxidation in soil occurs after the nitrogen has been fixed from the atmosphere. It is essential in transforming the ammonia in the soil into nitrites and nitrates that can be assimilated into plants. A study performed by Delgado-Baquerizo et al. (2016) in Australia looked at the abundance of ammonia-oxidizing genes along an aridity gradient in relation to biotic and abiotic features at microsites where the soil was collected. There was a strong positive correlation between aridity and ammoniaoxidizing archaea in all microsites, but there was little to no correlation between aridity and ammonia-oxidizing bacteria (Delgado-Baquerizo et al., 2016). Microsites that contained ant nests and high amounts of organic carbon in the soil had quadruple the amount of nitrate of open areas. Microsites that were open areas or consisting of biocrusts had 100-fold less ammonia-oxidizing bacteria genes in the soil than the other microsites (Delgado-Baquerizo et al., 2016). Higher abundance of ammonia-oxidizing bacteria and archaea would indicate the potential for either higher abundance of diazotrophs or higher occurrence of 
decomposition. The high abundance of ammonia-oxidizing bacteria implies that there are higher levels of ammonium in the soil. Since decomposition and nitrogen fixation are the two processes that produce soil ammonium, one process must be upregulated in the more arid sites.

\section{Impact of Research}

Few studies have focused on the effect of precipitation on diazotroph abundance in arid environments. Biogeochemical cycles are important to research in all environments in order to understand the potential effects of changing climates due to anthropogenic effects. Nitrogen fixation is a capability unique to microorganisms and is the main source of accessible soil nitrogen. This research will be essential for understanding how changing climate can affect the beginning of the nitrogen cycle, nitrogen fixation and nitrogenase gene abundance. I hypothesize that aridity will increase nitrogenase abundance. Elaine Bryant (2011) found that arid regions in the Mojave Desert had a large population of cyanobacteria, which fix nitrogen. This is consistent with other deserts and arid environments, which develop biological crusts which tend to have cyanobacteria. The Mojave Desert is unique, because its biological crusts are not as developed as crusts found in other deserts (Alwathnani and Johansen, 2011). There is evidence to support that there is increased ammonia-oxidation in arid environments by the presence of more ammonia-oxidizing bacterial genes (Delgado-Baquerizo et al., 2016), meaning that there is an accumulation 
ammonia in the soil that is available for oxidation. A potential reason for this would be an increase in the abundance of nitrogen fixing soil microorganisms. 


\section{References}

Alwathnani $\mathrm{H}$ and Johansen JR (2011). Cyanobacteria in Soils from a Mojave Desert Ecosystem. Monographs of the Western North American Naturalist, 5, 71-89.

Berges JA and Mulholland MR (2008). Enzymes and Nitrogen Cycling in Nitrogen in the Marine Environment (2 Edition) (pp.1385-1444). Cambridge, MA: Academic Press.

Bernhard A (2010). The Nitrogen Cycle: Processes, Players, and Human Impact. Nature Education Knowledge, 3(10), 25.

Bryant EP (2011). Differences in eubacterial and archaeal soil communities along a precipitation transect in the Mojave Desert. SJSU Scholarworks, 3913, http://scholarworks.sjsu.edu/etd_theses/3913

Delgado-Baquerizo M, Maestre FT, Eldridge DJ and Singh BK (2016). Microsite differentiation drives the abundance of soil ammonia oxidizing bacteria along aridity gradients. Frontiers in Microbiology, 7, 505.

Ecology of Fungi. (n.d.). Retrieved from https://courses.lumenlearning.com/boun dless-biology/chapter/ecology-of-fungi/

EPA (2017, January 19). Climate Impacts on Ecosystems. Retrieved from https://19january2017snapshot.epa.gov/climate-impacts/climate-impactsecosystems_html

EPA (n.d.). Greenhouse Gas Emissions. Retrieved from https://www.epa.gov/gh gemissions

Gardner R (n.d.). The Problem of Runoff. Retrieved from https://pesticidestew ardship.org/water/runoff/

Gornitz V, Rosenzweig C and Hillel D (1997). Effects of anthropogenic intervention in the land hydrologic cycle on global sea level rise. Global and Planetary Change, 14, 147-161.

Gosz JR, Likens GE and Bormann FH (1973). Nutrient release from decomposing leaf and branch litter in the Hubbard Brook Forest, New Hampshire. Ecological Monographs, 43(2), 173-191. 
Haddeland I, Heinke J, Biemans H, Eisner S, Florke M, Hanasaki N, Konzmann M, Ludwig F, Masaki Y, Schewe J, Stacke T, Tessler ZD, Wada Y and Wisser $D$ (2014). Global water resources affected by human interventions and climate change. Proceedings of the National Academy of Science, 111(9), 3251-3256.

Huntington TG (2006). Evidence for intensification of the global water cycle: review and synthesis. Journal of Hydrology, 319, 83-94.

Koberl M, Erlacher A, Ramadan EM, El-Arabi TF, Muller H, Bragina A and Berg $G$ (2016). Comparisons of diazotrophic communities in native and agricultural desert ecosystems reveal plants as important drivers in diversity. Federation of European Microbiological Societies Microbiology Ecology, 92, 1-11.

Lagzi I, Meszaros R, Gelybo G and Leelossy A (2013). Atmospheric Chemistry. Retrieved from http://elte.prompt.hu/sites/default/files/tananyagok/Atmos phericChemistry/index.html

Likens GE (1976). Acid precipitation. Chemical and Engineering News, 54, 2944.

Likens GE, Bormann FH and Johnson NM (1981). Interactions between major biogeochemical cycles in terrestrial ecosystems. Some Perspectives of the Major Biogeochemical Cycles, 93-112.

Likens GE, Bormann FH, Johnson NM, Fisher DW and Pierce RS (1970). Effects of forest cutting and herbicide treatment on nutrient budgets in the Hubbard Brook watershed-ecosystem. Ecological Monographs, 40(1), 23-47.

Likens GE, Bormann FH, Pierce RS, Eaton JS and Johnson NM (1977). Biogeochemisty of a Forested Ecosystem, New York, NY: Springer-Verlag.

Lindsey R and Dahlman L (2018, August 1). Climate Change: Global Temperature. https://www.climate.gov/news-features/understandingclimate/climate-change -global-temperature

Liu F, Huang G, Fallowfield H, Guan H, Zhu L and Hu H (2014). Study on heterotrophic-autotrophic denitrification permeable reactive barriers (HAD PRBs) for in-situ groundwater remediation. SpringerBriefs in Water Science and Technology, 9, 27-60. 
Lopez-Lozano NE, Carcano-Montiel MG and Bashan Y (2016). Using native trees and cacti to improve soil potential nitrogen fixation during long-term restoration of arid lands. Plant Soil, 403: 317-329.

Martinez-Espinosa RM, Cole JA, Richardson DJ and Watmough NJ (2011). Enzymology and ecology of the nitrogen cycle. Biochemical Society Transactions, 39(1), 175-178.

NASA (n.d.). Climate Change: How Do We Know? Retrieved from https://climate.nasa.gov/evidence/

Norman JS and Friesen ML (2017). Complex N acquisition by soil diazotrophs: how the ability to release exoenzymes affects $\mathrm{N}$ fixation by terrestrial freeliving diazotrophs. ISME Journal, 11 (2), 315-326.

Olson JB, Steppe TF, Litaker RW and Paerl HW (1998). $\mathrm{N}_{2}$ - fixing microbial Consortia associated with the ice cover of Lake Bonney, Antarctica. Microbial Ecology, 36, 231-238.

Orr CH, James A, Leifert C, Cooper JM and Cummings SP (2011). Diversity and activity of free-living nitrogen-fixing bacteria and total bacteria in organic and conventionally managed soils. Applied and Environmental Microbiology, 77, 911-919.

Poly F, Ranjard L, Nazaret S, Gourbiere F and Monrozier LJ (2001). Comparison of nifH gene pools in soils and soil microenvironments with contrasting properties. Applied and Environmental Microbiology, 67, 2255-2262.

Pongratz J, Reick CH, Raddatz T and Claussen M (2009). Effects of anthropogenic land cover change on the carbon cycle of the last millennium. Global Biogeochemical Cycles, 23, GB4001, doi:10.1029/2009GB003488.

Riebeek H (2011, June 16). The Carbon Cycle. Retrieved from https://earthobservatory.nasa.gov/Features/CarbonCycle.

Skot $L$ (2003). Genetic modification, applications: nitrogen fixation. In B Thomas (Ed.), Encyclopedia of Applied Plant Sciences (pp.413-419). Cambridge, MA: Academic Press.

Soderlund R (1977). NO pollutants and ammonia emissions - a mass balance for the atmosphere over Northwest Europe. AmBio, 6(2-3), 118-122. 
Vitousek PM (1999). Nutrient Limitation to Nitrogen Fixation in Young Volcanic Sites. Ecosystems, 2, 505-510.

What is a Harmful Algal Bloom (2016, April 27). Retrieved from https://www.noa a.gov/what-is-harmful-algal-bloom

Zehr JP, Jenkins BD, Short SM and Steward GF (2003). Nitrogenase gene diversity and microbial community structure: a cross system comparison. Environmental Microbiology, 5(7), 539-554. 


\section{Chapter 2: Manuscript}

\section{Introduction}

The nitrogen cycle is important for making nitrogen available to higher organisms. It involves a more diverse array of microorganisms compared to most other biogeochemical cycles. Abiotic factors are not the main contributors to nutrient cycling (Hayatsu et al., 2008). Arid and semi-arid regions represent $60 \%$ of global terrestrial area, yet only a few studies have focused on the effect of changes in climate on nitrogen cycling soil microorganisms in these areas (Belnap, 1995). Semi-arid and arid regions are threatened by desertification caused by anthropogenic effects, such as increased carbon dioxide levels and fluctuating precipitation amounts. Desertification occurs when the aridity of drylands increases to a point that vegetation and wildlife are threatened. These areas become infertile and soil biological processes including the hydrological cycle and nutrient cycling, are disrupted (Hillel and Rosenzweig, 2005).

The interaction between plants and the nitrogen cycle has been explored. Multiple studies have shown that the presence of plants increases diazotroph diversity (Orr et al., 2010; Koberl et al., 2015; Lopez-Lozano et al., 2015). However, Bryant (2011) found that in the Mojave Desert, the site with the least amount of vegetation coverage had the highest diversity and abundance of cyanobacteria, Clostridia and $\beta$-proteobacteria. The phylum Cyanobacteria and the classes Clostridia and $\beta$-proteobacteria include many species of diazotrophs. Bryant (2011) also found that there was an increase in abundance and diversity 
of the class Nitrospira, which consists of nitrite-oxidizing bacteria. These organisms contribute to the nitrification step of the nitrogen cycle. Other studies have found similar microbial diazotroph compositions in arid regions with limited vegetation. In arid Lake Bonney, Antarctica, diazotrophs from the classes Cyanophyceae, $a$-proteobacteria, $\delta$-proteobacteria, $\gamma$-proteobacteria, Clostridia, and Methanococci were found in soils and ice aggregates (Olson et al., 1998). Free-living diazotrophs do not require a symbiotic relationship with vegetation to grow as seen in both of these studies.

Aridity has also been shown to enhance other aspects of the nitrogen cycle. Delgado-Baquerizo et al. (2016) found that more arid regions had more ammonia-oxidizing genes in the soil, indicating the potential presence of more ammonia in the soil. The increased concentration of ammonia could be due to two different parts of the cycle, nitrogen fixation or decomposition. Decomposition is limited in more arid regions; therefore, it is unlikely to increase the ammonia in the soil (Likens et al., 1981). Also, as previously stated, vegetation that can be decomposed is typically decreased in arid environments. This suggests that there may be an increase in nitrogen fixation in these areas.

Some researchers have hypothesized that diazotrophs have a competitive advantage in areas that are nitrogen limited, such as deserts, as long as they are able to energetically support nitrogen fixation (Zehr et al., 2003; Vitousek, 1999). This hypothesis is supported by the fact that semi-arid and arid environments tend to have biological soil crust formation, which are communities of 
cyanobacteria, algae, fungi, and bryophytes (Alwathnani and Johansen, 2011; Belnap et al., 2001). Biological soil crusts thrive because of their symbiotic relationships that support nutrient cycling and prevent desiccation of organisms in the crust. In the Mojave Desert, Bryant (2011) found that there was a ten-fold decrease in the amount of nitrogen in the soil going from a semi-arid region to an arid region, as well as $80 \%$ increase in crust formation. This demonstrates that crusts dominated by cyanobacteria are more common in nitrogen limited areas of the Mojave Desert than areas with higher total nitrogen. The high number of cyanobacteria and the symbiotic relationships within biological soil crusts point to higher levels of nitrogen cycling.

This study focuses on the effect of precipitation amounts on nifH gene abundance in the Mojave Desert. nifH is the most conserved gene in the nitrogenase gene complex and is the standard gene to study when studying nitrogenase. In this study, quantitative PCR was used to estimate nifH gene abundance at four sites along a precipitation transect in the Mojave Desert. The gene copy number of the soil samples was analyzed over three years and an

analysis of variance (ANOVA) was used to determine if yearly precipitation had a significant effect. It was hypothesized that with increased aridity, there would be an increase in nifH abundance.

\section{Site Description}

The Mojave Desert is located in Southern California and ranges from arid to semi-arid. Arid is defined as having a ratio of mean annual precipitation to mean 
annual potential evapotranspiration between 0.03 to 0.20 , while the ratio for semi-arid is between 0.20 and 0.50 (UNEP, 1997). For the Mojave Desert, the mean annual precipitation ranges from 3.4 to 31 centimeters per year (Hereford et al., 2005).

From the year 2007 to the year 2010, soil samples were collected in collaboration with NASA's Spaceward Bound expedition. A 153-mile precipitation transect through the Mojave Desert was established. The sites along the transect decreased in elevation three-fold, and changes in rock and soil composition differed among the sites (Table 1).

Table 1. Sample sites in the Mojave Desert. Soil was collected from each of the four sites. Each site is listed with their number, name, location and elevation. Average rainfall was calculated from the average of rainfall for the 3 collection years (listed in Figure 2). Rock and soil types found in the immediate presence of the site are listed as well. Data collected by Bryant (2011).

\begin{tabular}{|c|c|c|c|c|c|c|}
\hline Site & $\begin{array}{l}\text { Latitude } \\
\left(0^{\circ}\right.\end{array}$ & $\begin{array}{l}\text { Longitude } \\
\left({ }^{\circ}\right)\end{array}$ & Elevation(m) & $\begin{array}{l}\text { Average } \\
\text { Rainfall }\end{array}$ & $\begin{array}{l}\text { Soil } \\
\text { Type }\end{array}$ & Rock Type \\
\hline $\begin{array}{l}\text { Site } 15 \\
\text { Sand } \\
\text { Canyon }\end{array}$ & N35.1230 & -118.3240 & 1212 & 21.94 & $\begin{array}{l}\text { Rich, } \\
\text { humic }\end{array}$ & None \\
\hline $\begin{array}{l}\text { Site } 16 \\
\text { California } \\
\text { City }\end{array}$ & N35.0218 & -117.9160 & 736 & 6.79 & $\begin{array}{l}\text { Sandy } \\
\text { silt }\end{array}$ & $\begin{array}{l}\text { Angular } \\
\text { quartz, } \\
\text { feldspar }\end{array}$ \\
\hline $\begin{array}{l}\text { Site } 18 \\
\text { Fields } \\
\text { Road }\end{array}$ & N35.0260 & -116.5400 & 630 & 6.84 & $\begin{array}{l}\text { Sandy } \\
\text { silt }\end{array}$ & $\begin{array}{l}\text { Feldspar, } \\
\text { granite }\end{array}$ \\
\hline $\begin{array}{l}\text { Site } 21 \\
\text { Henry } \\
\text { Springs } \\
\text { Rd }\end{array}$ & N35.2530 & -115.9790 & 403 & 9.65 & $\begin{array}{l}\text { Sandy } \\
\text { silt }\end{array}$ & $\begin{array}{l}\text { Quartz, } \\
\text { feldspar, } \\
5 \% \text { basalt }\end{array}$ \\
\hline
\end{tabular}


Diversity in rock types increased with more aridity, and soil changed from rich and humic in the semi-arid site to sandy silt in the arid sites. Yearly precipitation measurements were obtained from weather stations operated by the Desert Research Institute (DRI) in Las Vegas, Nevada (Figure 1) (Bryant, 2011). The yearly precipitation for each site was estimated by proximity to a weather station (Figure 2). Site 15, 16, and 21 were near the weather stations in Tehachapi, Mojave, and Baker respectively. Site 18 was equidistant from the Barstow and Zzyzx weather stations, so an average was taken for its estimate.

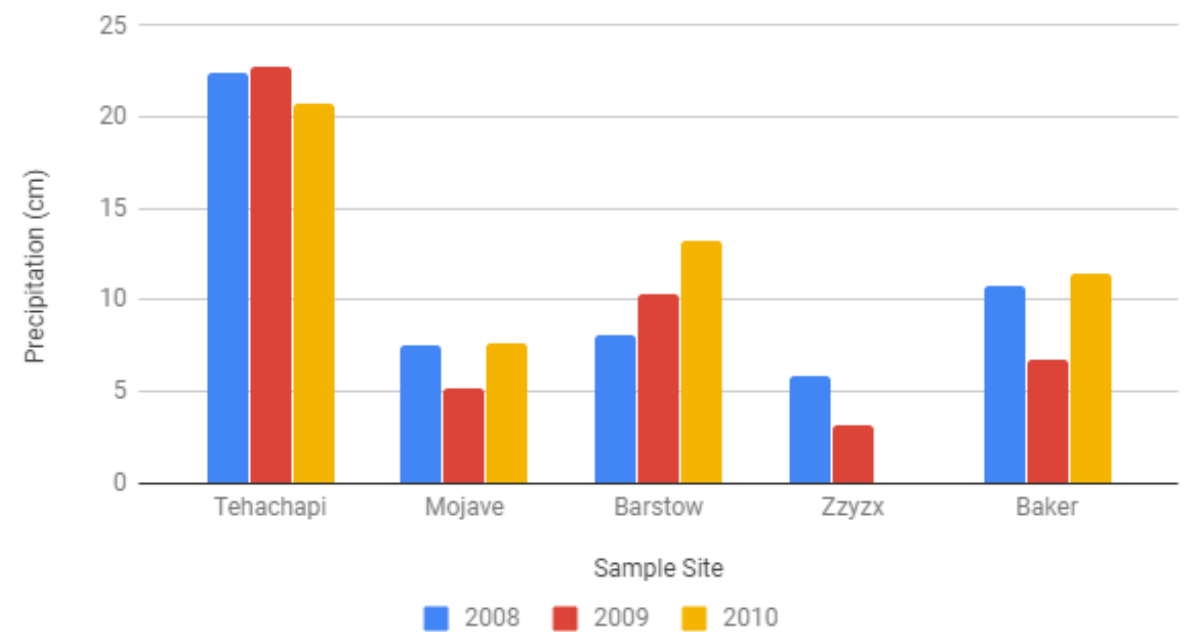

Figure 1. Precipitation amounts at DRI sites per year. Precipitation amounts (in $\mathrm{cm}$ ) recorded at regional DRI stations for a year prior to soil collection. No data was collected at site Zzyzx the year prior to the 2010 Spaceward Bound expedition. (Bryant, 2011) 


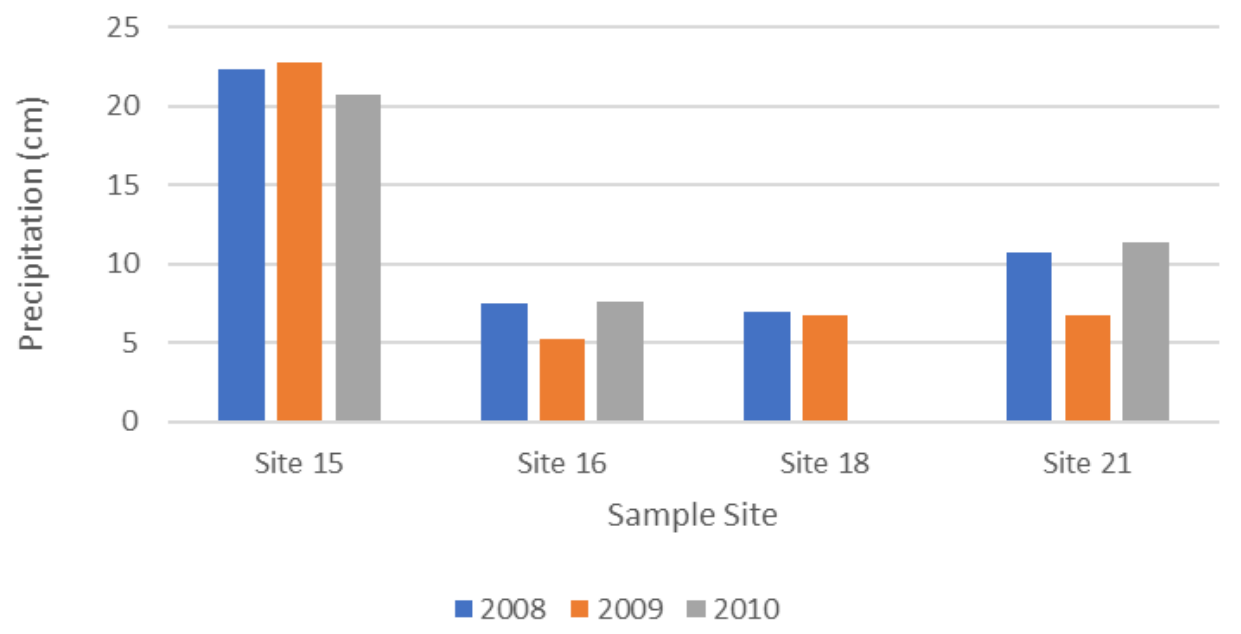

Figure 2. Precipitation amounts by year and site. Precipitation amount estimates (in $\mathrm{cm}$ ) for each soil collection site. Estimates were based on closest DRI station. Site 18 was located halfway between Barstow and Zzyzx, so its estimate is the average of the two precipitation amounts. In 2010, estimate could not be made for Site 18 due to missing site Zzyzx data. Data collected by Bryant (2011).

Soil composition and abiotic site factors were determined for the soils collected in 2009 and are listed in Table 2. Total nitrogen, percent organic carbon, percent moisture, and percent vegetation coverage decreased from the least to the most arid site. Conversely, percent crust increased across the precipitation transect. $\mathrm{pH}$ fluctuated across the transect, ranging from 7.18 to 7.88. The exact procedure for the soil collection was described in Bryant (2011). Chemical analysis of the soil was performed by Basic Laboratory, Inc. (Redding, California). 
Table 2. Soil composition and abiotic factors associated with 2009 sample sites. Quantitative soil and site factors were collected for the 2009 samples. $\mathrm{pH}$, total nitrogen, and percent organic carbon were analyzed in the soil. Percent crust, percent moisture, and vegetation coverage are variables of the site. Data collected by Bryant (2011).

\begin{tabular}{|l|l|l|l|l|l|l|}
\hline Site & $\mathrm{pH}$ & $\begin{array}{l}\text { Total } \\
\text { Nitrogen } \\
(\mathrm{mg} / \mathrm{kg})\end{array}$ & $\begin{array}{l}\% \text { Organic } \\
\text { Carbon }\end{array}$ & $\begin{array}{l}\% \\
\text { Moisture }\end{array}$ & $\begin{array}{l}\% \\
\text { Crust }\end{array}$ & $\begin{array}{l}\text { Vegetation } \\
\text { Coverage }\end{array}$ \\
\hline $\begin{array}{l}\text { Site 15 } \\
\text { Sand } \\
\text { Canyon }\end{array}$ & 7.18 & 1330 & 1.34 & 18.5 & 0 & $85-100 \%$ \\
\hline $\begin{array}{l}\text { Site 16 } \\
\text { California } \\
\text { City }\end{array}$ & 7.60 & 238 & 0.26 & 1.2 & 0 & $60-75 \%$ \\
\hline $\begin{array}{l}\text { Site 18 } \\
\text { Fields Road }\end{array}$ & 7.34 & 285 & 0.11 & 0.6 & 30 & $40-60 \%$ \\
\hline $\begin{array}{l}\text { Site 21 } \\
\text { Henry } \\
\text { Springs Rd }\end{array}$ & 7.88 & 111 & 0.18 & 0.18 & 80 & $25-45 \%$ \\
\hline
\end{tabular}

\section{Materials and Methods}

\subsection{Genomic DNA Extraction}

Anabaena sp. in Ala-Gro® Freshwater medium was purchased from Carolina® Biological Supply (Carolina $\AA^{\circledR}$, Burlington, NC). The Wizard® Genomic Purification Kit (Promega, Madison, WI) was used to extract genomic DNA from 1 $\mathrm{mL}$ of Anabaena sp. culture. The Gram-positive bacteria protocol was used to extract the Anabaena DNA. Soil genomic DNA was extracted from 0.5 grams of each soil sample using the DNeasy® PowerSoil® Kit (Qiagen, Hilden, Germany). Each kit was used according to the manufacturer's instructions. The DNA quality was assessed by $1 \%$ gel electrophoresis. The gel was stained with $0.5 \mu \mathrm{g} / \mathrm{mL}$ ethidium bromide and was visualized using UV transillumination on the Gel 
Doc $^{\text {TM }}$ EZ Gel Documentation System (Bio-Rad Laboratories, Inc., Hercules, $\mathrm{CA})$.

3.2 nifH Amplification from the Anabaena Genome

Degenerate primers were used to amplify the nifH gene via Polymerase Chain Reaction (PCR) in Anabaena sp. The forward and reverse primers used were IGK3 and DVV, respectively, and were synthesized by Fisher Scientific (Table 3). Eschericia coli was used as a negative control.

Table 3. nifH PCR primers. Primers used to amplify nifH gene as found in Gaby and Buckley (2012). The IUPAC nucleotide code was used. I = Inosine

\begin{tabular}{|l|l|}
\hline Primers & Coding (5'-3') \\
\hline IGK3 (forward) & GCIWTHTAYGGIAARGGIGGIATHGGIAA \\
\hline DVV (reverse) & ATIGCRAAICCICCRCAIACIACRTC \\
\hline
\end{tabular}

The PCR reactions had a total volume of $50 \mu \mathrm{L}$. The reagent concentrations were: 1x GoTaq® Flexi Buffer (Promega, Madison, WI), 2.5 mM MgCl $2,200 \mu \mathrm{M}$ dNTPs, $1.5 \mu \mathrm{M}$ of primers IGK3 and DVV, 0.2\% BSA, $2.5 \mathrm{U}$ GoTaq® DNA Polymerase (Promega, Madison, $\mathrm{WI}$ ). Four nanograms of Anabaena and eight nanograms of $E$. coli genomic DNA were used as template DNA. PCR was carried out in a MJ Research PTC 100 thermal cycler (Global Medical Instrumentation, Inc., Ramsey, MN). The cycling protocol consisted of an initial denaturation at $95{ }^{\circ} \mathrm{C}$ for 5 minutes, 34 cycles of $95{ }^{\circ} \mathrm{C}, 52{ }^{\circ} \mathrm{C}, 72{ }^{\circ} \mathrm{C}$ each for 45 seconds, and a final elongation step at $72{ }^{\circ} \mathrm{C}$ for 7 minutes. The PCR products 
were run on a $2 \%$ analytical agarose gel with Fisher BioReagents ${ }^{\mathrm{TM}}$ exACTGene $^{\text {TM }} 100$ bp ladder (Fisher Scientific, Hampton, NH). The gel was stained with $0.5 \mu \mathrm{g} / \mathrm{mL}$ ethidium bromide and was visualized using UV transillumination on the Gel Doc ${ }^{\mathrm{TM}}$ EZ Gel Documentation System (Bio-Rad Laboratories, Inc., Hercules, CA). The expected PCR product size was 400 bp.

3.3 Cloning and Sequencing of Anabaena nifH

PCR products were cloned into $\mathrm{PCR} \AA 2$ 2.1-TOPO® vectors using the TOPO® TA Cloning ${ }^{\circledR}$ Kit (Invitrogen, Carlsbad, CA) according to manufacturer's instructions. OneShot ${ }^{\circledR}$ Top10 Chemically Competent E. coli cells (Invitrogen, Carlsbad, CA) were transformed with the plasmids and assessed via blue/white screening. Three white colonies were grown in Luria-Bertani broth with $0.1 \mathrm{mg} / \mathrm{mL}$ ampicillin. The plasmids were extracted using the Wizard® Plus SV Minipreps DNA Purification System (Promega, Madison, WI). The plasmids were stored at $20^{\circ} \mathrm{C}$. The presence of the gene was verified by PCR amplification as well as sequencing by Sequetech (Mountain View, CA). The sequences were then compared to other known nucleotide sequences using BLAST (NCBI, Bethesda, $\mathrm{MD})$.

\subsection{Quantitative PCR (qPCR) Standard Curve}

A standard curve was created using the plasmid previously described. Tenfold dilutions were performed on the nifH plasmid by pipetting $10 \mu \mathrm{L}$ of plasmid sample into $90 \mu \mathrm{L}$ of sterile distilled water. This was repeated until a $10^{-6}$ dilution was obtained. Each $20 \mu \mathrm{L}$ qPCR reaction consisted of $1 \times$ Power SYBR ${ }^{\text {TM }}$ Green 
PCR Master Mix (Applied Biosystems, Foster City, CA) and $500 \mathrm{nM}$ of primers IGK3 and DVV. $5 \mu \mathrm{L}$ of dilutions $10^{-1}$ to $10^{-6}$, and negative controls of water, were added to the master mix, and sterile millipore water was added to each sample to obtain a final volume of $20 \mu \mathrm{L}$. Three replicates of each dilution were prepared. Primer concentration and annealing temperature were selected in order to reduce quantification bias as demonstrated by Gaby and Buckley (2017).

The samples were cycled in a Mx3005P qPCR System (Stratagene, La Jolla, CA). The following cycling protocol was used: 95 • for 10 minutes, followed by 65 cycles of 95 for 15 seconds, 52 for 1 minute, and 72 for 30 seconds. A standard curve was generated by a line of regression through all data points. The gene copy number for each dilution was calculated using the equation in Figure 3. A standard curve was generated by a line of regression through the mean of each dilution. Standard errors were shown using error bars.

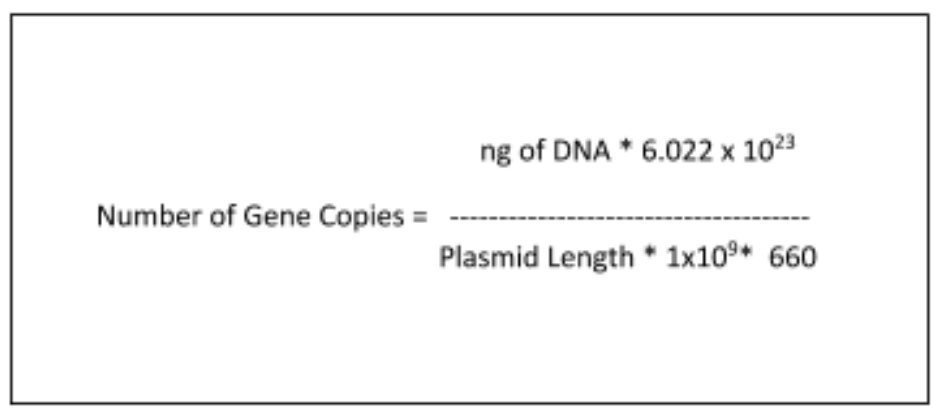

Figure 3. Equation to determine gene copy number. Nanograms of DNA were multiplied by Avogadro's Number and divided by the weight of each base pair in grams. ${ }^{*} 10^{\circ}$ represents the conversion from grams into nanograms. 
3.5 qPCR of Soil Samples from years 2008-2010

Thirty nanograms of soil genomic DNA and $500 \mathrm{nM}$ of primers IGK3 and DVV were added to $1 \mathrm{X}$ Power SYBR ${ }^{\mathrm{TM}}$ Green PCR Master Mix (Applied Biosystems, Foster City, CA). Water was added to a final volume of $20 \mu \mathrm{L}$. The samples were cycled in the Mx3005P qPCR system (Stratagene, La Jolla, CA) with the same cycling protocol described above for the standard curve samples. Total gene copy number was divided by the estimated bacteria population of one gram of soil as determined by viable counts previously described in Elaine Bryant's thesis (2011) (Table 4).

Table 4. Colony Forming Unit (CFU) count for each site and year. Population estimates per one gram of soil as measured by a viable count over three years and all four sites. Data collected by Bryant (2011).

\begin{tabular}{|c|c|c|c|}
\hline Site & $\mathbf{2 0 0 8}$ & $\mathbf{2 0 0 9}$ & $\mathbf{2 0 1 0}$ \\
\hline $\mathbf{1 5}$ & $1.5 \times 10^{8}$ & $1.5 \times 10^{7}$ & $4.2 \times 10^{7}$ \\
\hline $\mathbf{1 6}$ & $1.7 \times 10^{7}$ & $2.3 \times 10^{6}$ & $2.7 \times 10^{7}$ \\
\hline $\mathbf{1 8}$ & $1.3 \times 10^{7}$ & $3.3 \times 10^{7}$ & $3.4 \times 10^{6}$ \\
\hline $\mathbf{2 1}$ & $3.0 \times 10^{6}$ & $2.7 \times 10^{6}$ & $2.6 \times 10^{6}$ \\
\hline
\end{tabular}

\subsection{Statistical Analysis}

Statistical analysis was performed using $R$ software (R Core Team, 2013). ttests were used to determine significant differences between sites. ANOVAs were used to determine significant interactions between abiotic factors and sites. Two-way ANOVAs were used to determine interactions between multiple factors and gene copy amounts. A significance level of 0.05 was set for all statistics. 


\section{Results}

\subsection{Cloning and Sequencing}

$400 \mathrm{bp}$ was the length of the DNA fragment amplified from Anabaena sp. in the initial PCR amplification and is the expected length of the nifH gene fragment when amplified with IGK3 and DVV primers. nifH PCR amplification of the plasmid DNA resulted in a band approximately $400 \mathrm{bp}$ in length. The sequencing results revealed a $93 \%$ similarity between the cloned sequence and the nifH gene in Anabaena cylindrica strain UTEX B629 $($ Score $=409$, E-value $=6 e-110)$ Figure 4 shows the similarities between the cloned sequence and Anabaena cylindrica's nifH gene.

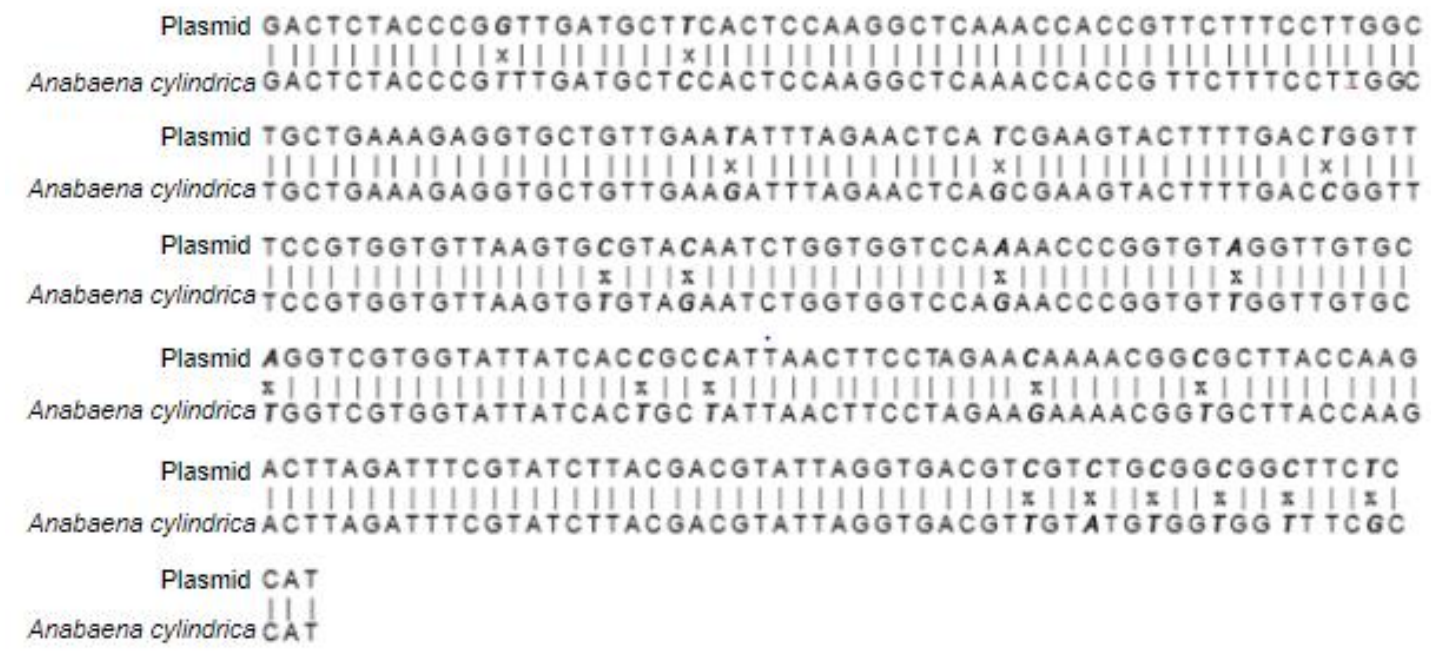

Figure 4. Comparison of cloned sequence to $\mathrm{nifH}$ sequence in Anabaena cylindrica strain UTEX B629 (Sequence ID: AY768423.1). NCBI BLAST results for cloned sequence matched $93 \%$ with nifH gene in Anabaena cylindrica. Matched nucleotides are denoted with a vertical line, and mismatched nucleotides are indicated by an $\mathrm{x}$. 


\section{2 qPCR Standard Curve}

The means of the cycle thresholds $\left(\mathrm{C}_{1}\right)$ were averaged and the standard deviations were calculated. A standard curve was generated from the means (Figure 5). An $\mathrm{R}^{2}$ of 0.998 was calculated using Microsoft Excel (2016). An equation was derived from the regression line, which was used to calculate the gene copy numbers for the soil sites. The equation of the standard curve is $y=2 E+12 e^{-0.374 x}$.

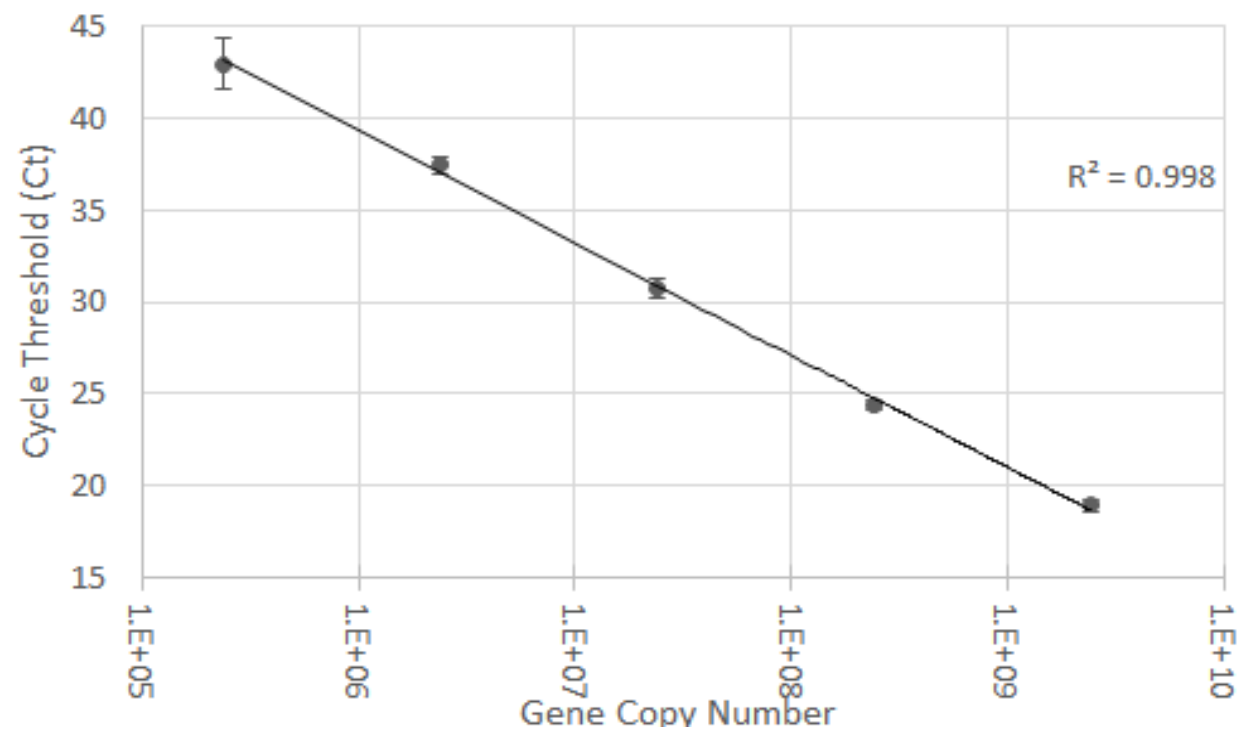

Figure 5. Standard curve generated from qPCR of cloned nifH gene in plasmid. Each point represents the mean of the replicates of each dilution. Error bars represent the standard error of each mean. The $x$ axis is on a log scale.

4.3 qPCR of Soil Samples from years 2008-2010

The average nifH gene copy number of site 15 over the years 2008-2010 was $8,976 \pm 15,083$ gene copies. Site 16 had an average gene copy number of $36,036 \pm 66,554$ gene copies. Site 18 had an average of $66,249 \pm 111,741$ gene 
copies, and site 21 had an average of $95,324 \pm 113,894$ gene copies. Over all sites, the average for the year 2008 was $63,655 \pm 90,668$ gene copies. The average for 2009 was $48,875 \pm 82,171$, and 2010 had an average of $56,601 \pm$ 109,930 copies. The total nifH gene copy number fluctuated by year but had a trend of increased copy number at the more arid sites (Figure 6). All site 15 years were significantly different from 2009 site 21 (2008: $p=0.050,2009: p=0.036$, 2010: $p=0.032) .2008$ site 16 and 2010 site 18 also were significantly different from 2009 site 21 ( $p=0.0448, p=0.345)$. There was a significant difference between 2009 site 15 and 2010 site $15(p=0.047)$.

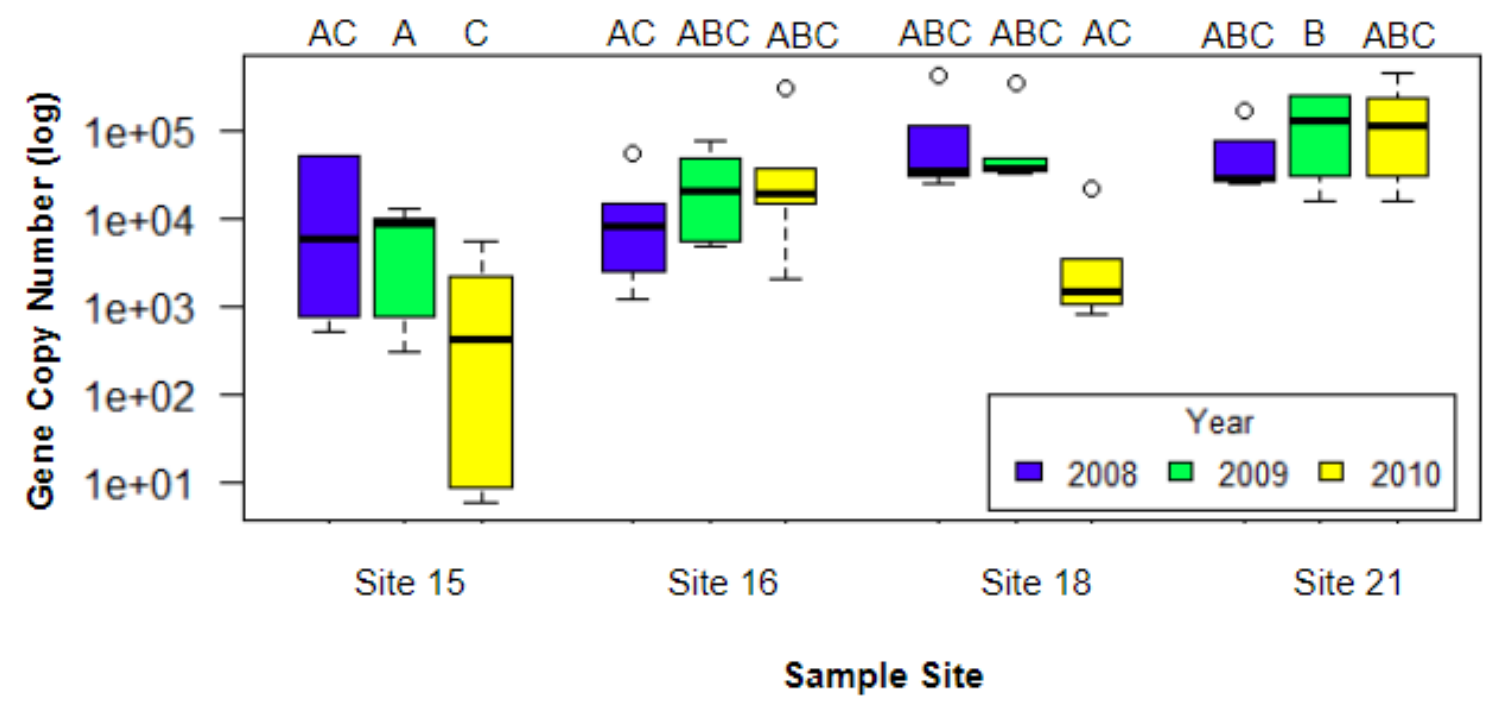

Figure 6. Total gene copy number of sample sites. Gene copy numbers were plotted by sites and year. Significance values of 0.05 and below are signified by difference in letters. $n=6$

Gene copy number was adjusted by dividing the total gene copy number by the viable count population estimate of one gram of soil. The adjusted gene copy number fluctuated by year for site 16 and site 18 but stayed consistent in site 15 
and site 21 (Figure 7). There was a trend of higher gene copy proportional to population in more arid sites. 2009 site 21 was significantly different from all years of site 15 (2008: $p=0.031,2009: p=0.031,2010: p=0.030), 2008$ site 16 $(p=0.032)$, and 2010 site $18(p=0.034) .2009$ site 15 was significantly different from 2010 site $15(p=0.028)$.

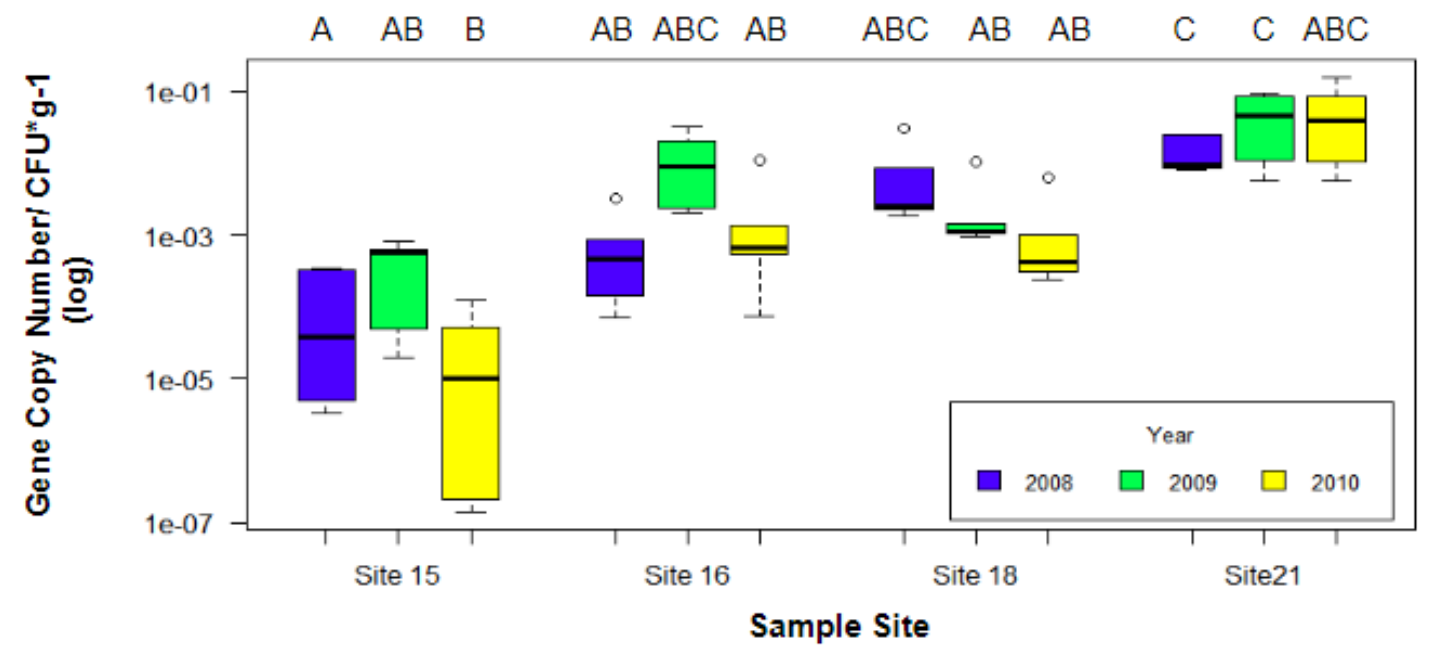

Figure 7. Adjusted gene copy number of sample sites. Gene copy number adjusted by viable counts shown in Table 4. qPCR results were divided by population estimates in Table 4. $p$-values under the significance level of 0.05 are indicated by differences in letters. $n=6$

\subsection{Statistical Analysis}

Site number and yearly precipitation had significant effects on total gene copy number $(p=3.64 \mathrm{e}-4, p=0.027$ ) (Table 5). Year, the combination of year and precipitation, year and site, and site and precipitation did not have a significant effect on nifH total gene copy number over the three years. Site and the 
combination of site and year had significant effects on gene copy number /CFU ${ }^{*} g^{-1}(p=4.46 \mathrm{e}-07, p=0.040)$ (Table 6).

Table 5. Total gene copy number vs site factors over 3 years. Site, year, precipitation, and combinations of these factors were analyzed in respect to their effect on nifH gene copy number. Site and yearly precipitation had a significant effect on gene copy number. '*' represents a significance level of 0.05 . '\#' refers to the exclusion of data from 2010 site 18 due to missing precipitation data.

\begin{tabular}{|l|l|}
\hline Factors & $p$-value \\
\hline Site & $3.64 \mathrm{e}-4^{\star}$ \\
\hline Year & 0.782 \\
\hline Precipitation \# & $0.027^{\star}$ \\
\hline Site + Year & 0.263 \\
\hline Site + Precipitation \# & 0.643 \\
\hline Year + Precipitation \# & 0.323 \\
\hline
\end{tabular}

Table 6. Adjusted gene copy number vs site factors for 3 years. Site, year, precipitation, and combinations of these factors were analyzed in respect to their effect on the adjusted gene copy number. Site had a significant effect on gene copy number. '*' represents a significance level of 0.05 . '\#' refers to the exclusion of data from 2010 site 18 due to missing precipitation data.

\begin{tabular}{|l|l|}
\hline Factors & $p$-value \\
\hline Site & $4.46 \mathrm{e}-07^{\star}$ \\
\hline Year & $\mathbf{0 . 3 2 0}$ \\
\hline Precipitation \# & 0.096 \\
\hline Site + Year & $\mathbf{0 . 0 4 0 ^ { \star }}$ \\
\hline Site + Precipitation \# & $\mathbf{0 . 9 3 1}$ \\
\hline Year + Precipitation \# & $\mathbf{0 . 5 1 8}$ \\
\hline
\end{tabular}


In Figure 8, the $p$-values of ANOVAs between abiotic site and soil composition factors and gene copy number were plotted on a dot plot. $p$-values to the left of the red line are less than 0.05 . Percent vegetation, percent crust, and site number had significant effects on the total nifH copy number in the 2009 sites $(p=.009, p=0.010, p=0.008)$.
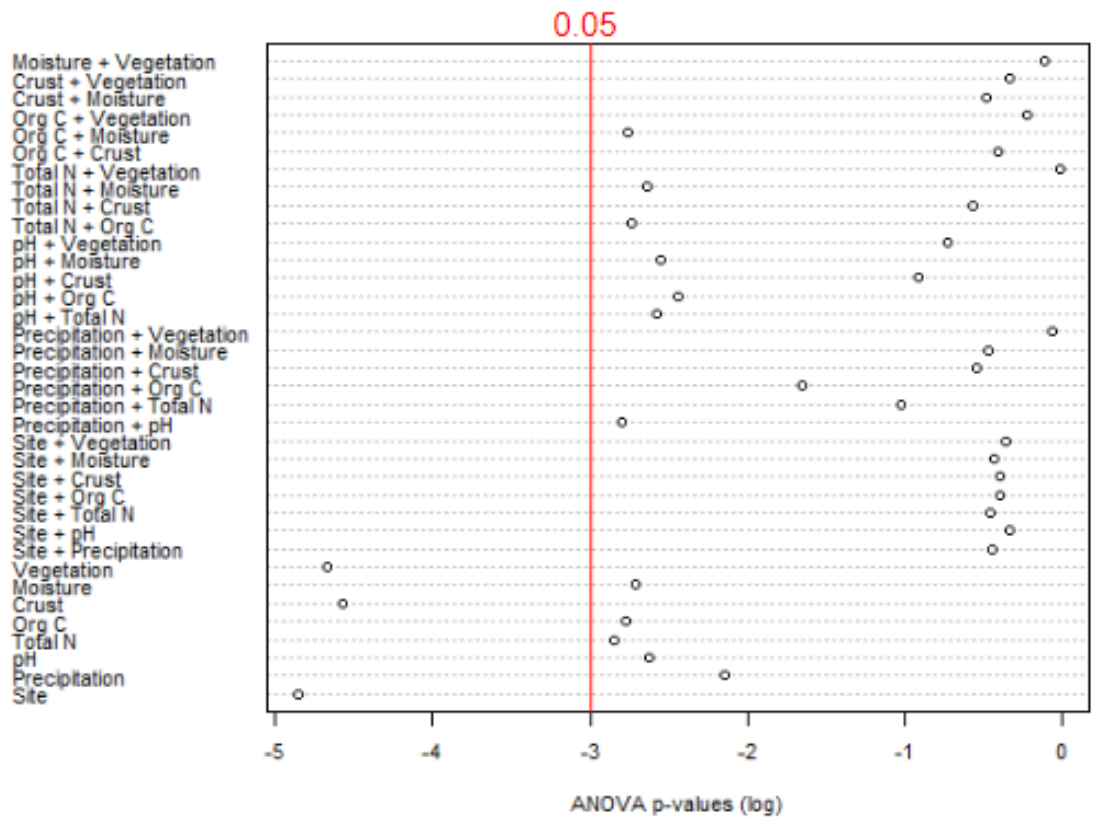

Figure 8. ANOVA of 2009 soil and site composition factors on total gene copy number. The $p$-value of each factor is represented as a dot on the dot plot. $p$ values to the left of the 0.05 line are less than 0.05 .

A similar dot plot was compiled for the bacterial population adjusted gene copy number. Many factors had a significant effect on the adjusted nifH copy number (Figure 9$)$. Site number $(p=0.002), \mathrm{pH}(p=4.15 \mathrm{e}-04)$, total nitrogen $(p=0.046)$, percent crust $(p=0.001)$, and percent vegetation $(p=0.009)$ were single factors that had significant effects. Precipitation, percent organic carbon, and 
percent moisture did not have significant effects as single factors. $\mathrm{pH}$ when interacting with any other factor did not have a significant effect on adjusted gene copy number. The interactions of site with all other factors besides $\mathrm{pH}$ had significant effects on the adjusted gene copy number (precipitation: $p=0.031$, total $\mathrm{N}: p=0.030$, org C: $p=0.037$, crust: $p=0.038$, moisture: $p=0.032$, vegetation: $p=0.047)$. Precipitation also had a significant effect when interacting with percent organic carbon, percent crust, percent moisture, and percent vegetation $(p=6.51 \mathrm{e}-04, p=0.040, p=0.002, p=0.009)$. When interacting with percent moisture, percent crust, percent organic carbon, and total nitrogen, percent vegetation had significant effects as well ( $p=0.011, p=0.039, p=0.020, p=0.007)$. The interaction of organic carbon with percent moisture, percent crust, and total nitrogen had a significant effect on adjusted gene copy number $(p=0.005$, $p=0.038, p=0.037)$. Lastly, percent crust had a significant effect when interacting with total nitrogen and percent moisture $(p=0.041, p=0.039)$. 

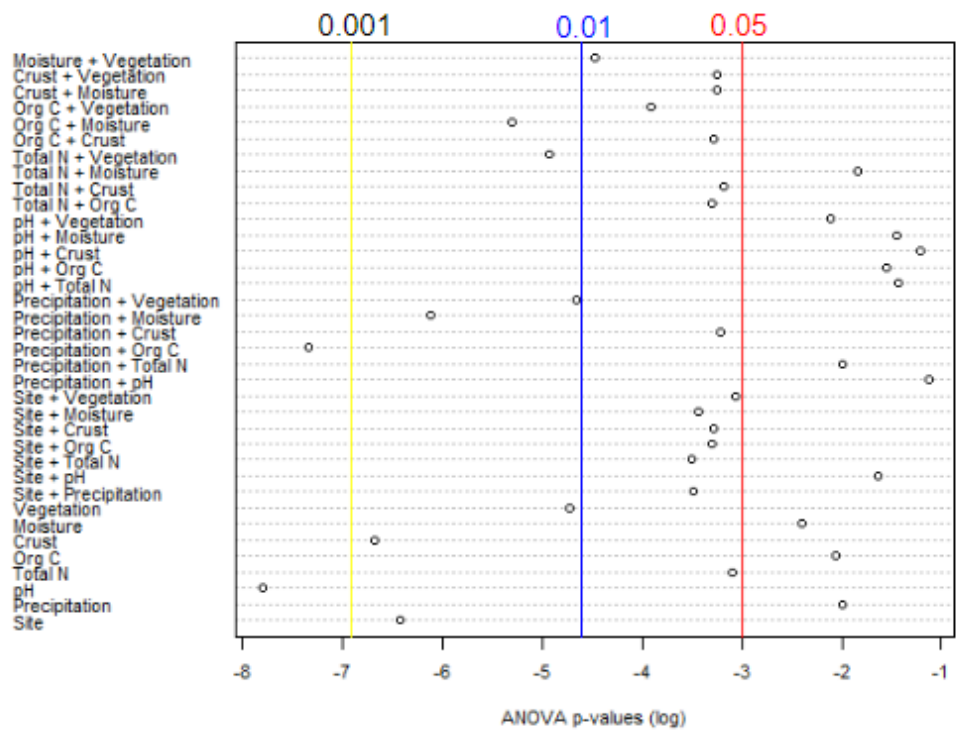

Figure 9. ANOVA of 2009 soil and site composition factors on adjusted gene copy number. ANOVA $p$-values are plotted on the dot chart for different factors and combinations of factors. $0.001,0.01$, and 0.05 significance levels are indicated by the colored lines.

Principal component analysis (PCA) was used to determine correlation among sites using the 2009 abiotic factors, total gene copy number, and adjusted gene copy number. Two principal components were produced that accounted for $87.3 \%$ of the total variance $(\mathrm{PC} 1=70.57 \%, \mathrm{PC} 2=16.73 \%)$. The semi-arid site, site 15 , was different from the arid sites, sites 16,18 , and 21 , when a normal distribution ellipse was utilized (Figure 10a). Figure 10b shows the breakdown of the different sites. Fields Rd (site 18) and California City (site 16) showed closest clustering of the four sites. 
a)

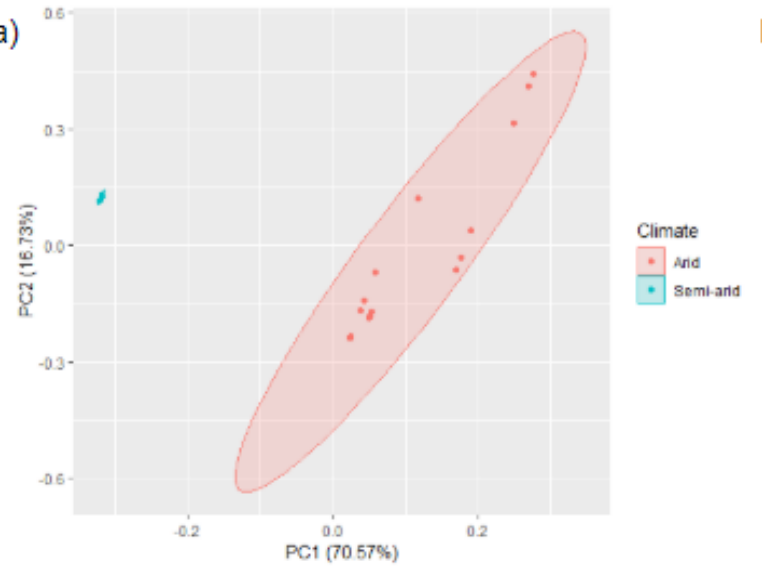

b)

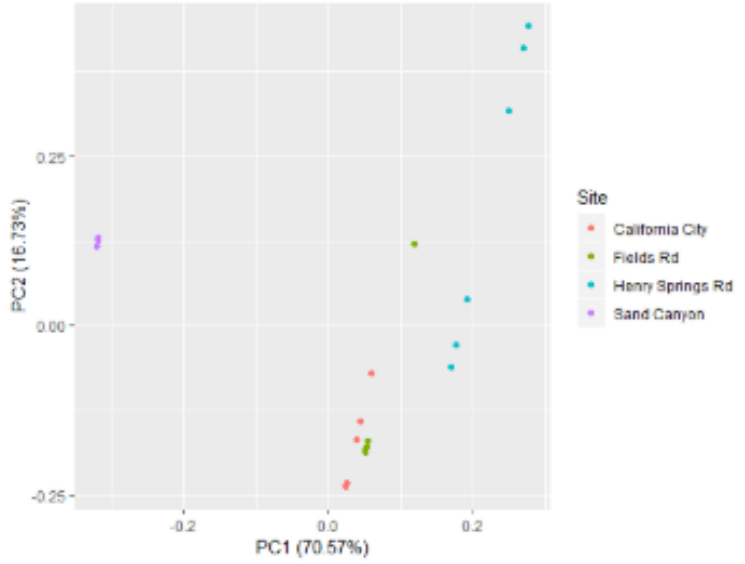

Figure 10. PCA of 2009 factors. a) 2009 abiotic factors, total gene copy numbers, and adjusted gene copy numbers were analyzed using PCA. A normal distribution was used to frame the different climates. b) The same factors were differentiated by site. Site $15=$ Sand Canyon, Site 16 = California City, Site 18 = Fields Rd, Site $21=$ Henry Springs Rd

\section{Discussion}

Arid environments cover up to $40 \%$ of the surface of the earth, potentially more with the increasing surface temperature, yet there has been little research on biogeochemical cycling in these regions. The effect that changing precipitation has on nitrogen cycling is important to understand since changing climate could affect the microorganisms that catalyze the reactions within the cycle.

In this study, nifH copy number in soil microbial populations was determined using quantitative PCR. There was a trend of higher gene copy numbers in more arid sites. Arid regions tend to have biological soil crusts, which are commonly populated by cyanobacteria. These organisms are photosynthetic diazotrophs (Alwathnani and Johansen, 2011; Mogul et al., 2017). Alwathnani and Johansen 
(2011) isolated 90 strains of cyanobacteria from the biological soil crust of six sites in the Mojave Desert near Fort Irwin National Training Center, 36 miles north of Barstow, CA. The known strains encompassed 12 genera. Mogul et al. (2017) found that cyanobacteria dominated the topsoil in the Mojave Desert, comprising of $33 \%$ of known phyla. The most arid region in this study, site 21 , had $80 \%$ crust and $35 \%$ of its bacterial population was cyanobacteria (Bryant, 2011). These observations support the results of the study.

In addition, there was a trend of higher proportions of nifH gene copies in the more arid sites. Proportion was determined by dividing the total gene copy number by viable count population estimates for one gram of soil. When the total gene copy number was divided by viable count population estimates, larger values were observed in the more arid region. This proportion does not necessarily mean that there is an increase in the number of diazotrophs in the population. Multiple species of bacteria have multiple nifH gene copy numbers. Cyanobacteria can have up to six copies, but the copy number can change with the number of heterocysts they form (Pratte et al., 2006). Since the species of bacteria for each sample is unknown, the adjusted proportion reflects the upper limit of the population's percentage of diazotrophs. The adjusted proportion assumes 1:1 ratio of genes per bacterium. A similar approach has been used to estimate the number of antibiotic resistance genes in aquatic microorganisms by Suzuki et al. (2015). They demonstrated that there was a higher percentage of 
drug resistant genes in bacterial populations in urban rivers and wastewater treatment plants than in rural rivers.

Site and yearly precipitation amounts were found to have a significant effect on nifH copy number. Percent vegetation and percent crust also had a significant effect in the 2009 sites. The effect of percent crust is expected due to the presence of cyanobacteria. Much research has been done on the symbiotic relationship between plants and diazotrophs. Lopez-Lozano et al. (2016) studied the effect of different plant species on free-living diazotrophs in the soil. When compared to soil without plants, soil containing plants showed a higher average activity in an acetylene reduction assay as well as higher average diazotroph diversity. Similarly, Koberl et al. (2015) found that there were significantly higher nifH abundance and diversity in agricultural soils and soils dominated by plants than desert soil. They found there was a 1.5 -fold increase in nifH abundance in agricultural soils. There was also a greater nifH diversity at both genus and class levels. The results of this study contradict these observations. There are higher gene copy numbers in areas with less vegetation. This could be due to the reduction of vegetation litter, which would decrease the amount of nitrogen in the soil. It has been proposed that less nitrogen in the soil gives an advantage to diazotrophs as long as they have enough phosphorus available to be energetically stable (Zehr et al., 2003; Vitousek, 1999).

$\mathrm{pH}$, total nitrogen, percent crust, and percent vegetation had significant effects on the proportion of nifH genes in the microbial population as determined 
by dividing total gene copy number by population estimates of one gram of soil. In this study, site 21 had the highest $\mathrm{pH}$ and the most gene copies. This observation is supported by reports that low $\mathrm{pH}$ led to significant reduction of nitrogenase activity in soil (Schubert et al., 1990). Genetic data were not collected, but the authors predicted the reduction was due to excess hydrogen ions in the soil. This study also determined that total nitrogen was low in the sites with the highest gene copies. Previously it was found that nitrogenase activity was decreased when urea was added to rice soil as a nitrogen source (Ayuni et al., 2015). This could be due to reduction of nitrogenase genes in high nitrogen environments. Diazotrophs thrive in regions with depleted nitrogen since they do not need to compete for the limited nitrogen.

There were a few limitations to this study. First, diazotrophs have varying amounts of nifH copies. For example, Klebsiella pneumoniae has one nifH gene copy, Paenibacillus azotofixans has three, and Clostridium pasteurianum has six copies (Hong et al., 2012). Also, since cyanobacteria can have two copies of nifH per heterocyst, it would be difficult to tell if there truly was a higher proportion of diazotrophs or simply diazotrophs with higher numbers of heterocysts in the soil (Pratte et al., 2006). This study also does not look at diazotroph activity, only gene abundance. Gene abundance is not indicative of enzyme activity only enzyme potential. Enzyme activity increases and decreases over time and can be influenced by bacterial diversity (Philippot et al., 2013). For example, denitrification activity was attenuated when microbial diversity was decreased, 
even when there was not a significant difference in nos $Z$ gene copy number (Philippot et al., 2013). The previous study performed by Bryant (2011) demonstrated a higher diversity in site 21 , which could imply that there is not only the highest nitrogenase potential, but also perhaps the highest activity in that site.

My future directions would be to analyze nifH gene diversity within the four sites used in this study. Bryant (2011) previously analyzed 16S rRNA genetic diversity at these sites, but the genetic diversity for the nifH gene has not been studied. Poly et al. (2001) concluded using gene pool analysis that differences in the nifH gene pools may be manipulated by inorganic nitrogen in temperate environments. They were able to demonstrate, using PCA analysis, that forest and cultivated soils had similar RFLP profiles, but both were different from permanent pasture soils. Permanent pasture soils were different from each other as well. They hypothesized that this could be due to the soils having distinct levels of inorganic nitrogen. Understanding the structure of the nifH gene pools at the study sites will elucidate how microbial diversity changes among the sites and what environmental drivers influence diversity in arid soils.

Measuring the activity of nitrogenase itself would also be useful. One method used to determine nitrogenase activity is acetylene reduction assay, which uses gas chromatography to quantify the reduction of acetylene gas to ethylene by the nitrogenase enzyme. Acetylene reduction assay has been used in experiments to show diazotroph activity in soil associated with different plants in arid 
environments and in soils with different sources and quantities of nitrogen (Lopez-Lozano et al., 2016; Ayuni et al., 2015). Lopez-Lozano et al. (2016) used the assay to show that nitrogenase was significantly more active around mesquite trees in the Sonoran Desert than soil without plants. Ayuni et al. (2015) used the acetylene reduction assay to show that urea inhibited nitrogenase activity in diazotrophs. It is a useful method, because it measures nitrogenase activity instead of relying on assumptions made from genetic information. Analyzing the RNA of these samples could also help elucidate both genetic diversity and nitrogenase activity, because it looks at not only the order of the nucleotides but also the amount of transcription taking place. Reverse transcription-qPCR (RT-qPCR) and operational taxonomic unit (OTU) analysis were used by Calderoli et al. (2017) to demonstrate that diazotrophs were abundant under soybean crops in the Argentinean Pampas. They also showed that in no-till agricultural soil, diazotroph diversity was influenced by soil stability and organic carbon. RNA isolation would be useful because of its ability to understand both enzyme activity and diversity information.

\section{Conclusions}

This research focused on how one step of the nitrogen cycle is affected by precipitation in an arid region. The gene $\mathrm{nifH}$ increases in abundance in more arid regions of the Mojave Desert. Yearly precipitation has a significant effect on the total gene copy number. Other site and soil composition factors, such as percent vegetation and percent crust, also influence total gene copy number. 
Future research is needed to help understand the effect on changes in climate on biogeochemical cycling. 


\section{References}

Alwathnani $\mathrm{H}$ and Johansen JR (2011). Cyanobacteria in Soils from a Mojave Desert Ecosystem. Monographs of the Western North American Naturalist, 5, 71-89.

Ayuni N, Radziah O, Naher UA, Panhwar QA and Halimi MS (2015). Effect of nitrogen on nitrogenase activity of diazotrophs and total bacterial population in rice soil. Journal of Animal and Plant Sciences, 25(5), 1358-1364.

Belnap J (1995). "Surface disturbances: their role in accelerating desertification," In Desertification in Developed Countries, eds D.A. Mouat and C.F. Hutchinson (Berlin:Springer), 39-57.

Belnap J, Budel B and Lange OL (2001). Biological Soil Crusts: Characteristics and Distribution in Biological Soil Crusts: Structure, Function, and Management, vol 150. Springer, Berlin, Heidelberg.

Bryant EP (2011). Differences in eubacterial and archaeal soil communities along a precipitation transect in the Mojave Desert. SJSU Scholarworks, 3913, http://scholarworks.sjsu.edu/etd_theses/3913

Calderoli PA, Collavino MM, Behrends Kraemer F, Morras HJM and Aguilar OM (2017). Analysis of nifH-RNA reveals phylotypes related to Geobacter and Cyanobacteria as important functional components of the N2 -fixing community depending on depth and agricultural use of soil. Microbiologyopen, 6(5), 1-15.

Delgado-Baquerizo M, Maestre FT, Eldridge DJ and Singh BK (2016). Microsite differentiation drives the abundance of soil ammonia oxidizing bacteria along aridity gradients. Frontiers in Microbiology, 7, 505.

Gaby JC and Buckley DH (2012). A comprehensive evaluation of PCR primers to amplify the nifH gene of nitrogenase. PLoS ONE, 7(7), e42149, doi:10.1371/journal.pone.0042149

Gaby JC and Buckley DH (2017). The use of degenerate primers in qPCR analysis of functional genes can cause dramatic quantification bias as revealed by investigation of nifH primer performance. Microbial Ecology, 74, 701-708.

Hayatsu M, Kanako T and Saito M (2008). Various players in the nitrogen cycle: Diversity and functions of the microorganisms involved in nitrification and 
denitrification. Journal of Social Science and Plant Nutrition, 54, 33-45.

Hereford R, Webb RH and Longpre Cl (2005, April 4). Precipitation History of the Mojave Desert Region, 1893-200. Retrieved from https://pubs.usgs. $\mathrm{gov} / \mathrm{fs} / \mathrm{fs} 117-03 /$

Hillel D and Rosenzweig C (2005). Desertification. Encyclopedia of Soils in the Environment, 382-389.

Hong Y, Ma Y, Wu L, Maki M, Qin W and Chen S (2012). Characterization and analysis of nifH genes from Paenibacillus sabinae T27. Microbiological Research, 167(20), 596-601.

Koberl M, Erlacher A, Ramadan EM, El-Arabi TF, Muller H, Bragina A and Berg $G$ (2016). Comparisons of diazotrophic communities in native and agricultural desert ecosystems reveal plants as important drivers in diversity. Federation of European Microbiological Societies Microbiology Ecology, 92, 1-11.

Likens GE, Bormann FH and Johnson NM (1981). Interactions between major biogeochemical cycles in terrestrial ecosystems. Some Perspectives of the Major Biogeochemical Cycles, 93-112.

Lopez-Lozano NE, Carcano-Montiel MG and Bashan Y (2016). Using native trees and cacti to improve soil potential nitrogen fixation during long-term restoration of arid lands. Plant Soil, 403: 317-329.

Makhalanyane TP, Valverde A, Gunnigle E, Frossard A, Ramond J and Cowan DA (2015). Microbial ecology of hot desert edaphic systems. Federation of European Microbiological Societies Microbiology Reviews, 39, 203-221.

Mogul R, Vaishampayan P, Bashie M, McKay CP, Schubert K, Bornaccorsi R, Gomez E, Tharayil S, Payton G, Capra J, Andaya J, Bacon L, Bargoma E, Black D, Boos K, Brant M, Chabot M, Chau D, Cisneros J, Chu G, Curnutt J, DiMizio J, Engelbrecht C, Gott C, Harnoto R, Hovanesian R, Johnson S, Lavergne B, Martinez G, Mans P, Morales E, Oei A, Peplow G, Piaget R, Ponce N, Renteria E, Rodriguez V, Rodriguez J, Santander M, Sarmiento K, Scheppelmann A, Schroter G, Sexton D, Stephenson J, Symer K, Russo-Tait T, Weigel B and Wilhelm MB (2017). Microbial community and biochemical dynamics of biological soil crusts across a gradient of surface coverage in the central Mojave Desert. Frontiers in Microbiology, 8:1974.

Olson JB, Steppe TF, Litaker RW and Paerl HW (1998). $\mathrm{N}_{2}$ - fixing microbial Consortia associated with the ice cover of Lake Bonney, Antartica. Microbial Ecology, 36, 231-238. 
Orr CH, James A, Leifert C, Cooper JM and Cummings SP (2011). Diversity and activity of free-living nitrogen-fixing bacteria and total bacteria in organic and conventionally managed soils. Applied and Environmental Microbiology, 77, 911-919.

Philippot L, Spor A, Henault C, Bru D, Bizouard F, Jones CM, Sarr A and Maron $P$ (2013). Loss in microbial diversity affects nitrogen cycling in soil. International Society for Microbial Ecology, 7, 1609-1619.

Poly F, Ranjard L, Nazaret S, Gourbiere F and Monrozier LJ (2001). Comparison of nifH gene pools in soils and soil microenvironments with contrasting properties. Applied and Environmental Microbiology, 67, 2255-2262.

Pratte BS, Eplin K and Thiel T (2006). Cross-functionality of nitrogenase components $\mathrm{NifH} 1$ and $\mathrm{VnfH}$ in Anabaena variabilis. Journal of Bacteriology, 188, 5806-5811.

R Core Team (2013). R: A language and environment for statistical computing. R Foundation for Statistical Computing, Vienna, Austria.URL. http://www.R-project.org/.

Schubert E, Mengel K and Schubert S (1990). Soil pH and calcium effect on nitrogen fixation and growth of broad bean. Agronomy Journal (USA), 82, 969-972.

Suzuki S, Ogo M, Koike T, Takada H and Newman B (2015). Sulfonamide and tetracycline resistance genes in total- and culturable-bacterial assemblages in South African aquatic environments. Frontiers in Microbiology, 6, 42-49.

UNEP (United Nations Environment Programme) (1997). World atlas of desertification 2ED. London, UK: UNEP.

Vitousek PM (1999). Nutrient Limitation to Nitrogen Fixation in Young Volcanic Sites. Ecosystems, 2, 505-510.

Zehr JP, Jenkins BD, Short SM and Steward GF (2003). Nitrogenase gene diversity and microbial community structure: a cross system comparison. Environmental Microbiology, 5(7), 539-554. 